\title{
THE «BOYHOOD FRIENDS» OF ALEXANDER THE GREAT
}

\begin{abstract}
The «boyhood friends» of Alexander the Great, who were banished by Philippos for their part in the «Pixodaros affairn, were not Alexander's contemporaries, but his elder advisors. Philippos banished them because they gave advice against his own interests.
\end{abstract}

Probably in early 336 B. C. ${ }^{1}$, Philip II banished five hetairoi of Alexander for their part in the so-called «Pixodaros affair»: Harpalos, Nearchos, Ptolemaios (son of Lagos), and the brothers Erigyios and Laomedon (Arr. III 6, 5f.; Plut. Alex. 10). They are generally, and I think incorrectly, considered Alexander's boyhood friends, i.e., his contemporaries. Hence our interpretation of Alexander's position at the Court shortly before his father's assassination is affected in no small way by the importance we attach to these hetairoi. If they were, in fact, his closest boyhood friends, then we might share J. R. Hamilton's view that their exile left the Crown Prince «isolated" at the Court ${ }^{2}$. Similarly, W. W. Tarn saw some significance in Hephaistion's exclusion from those who were banished, but he reached the false conclusion that Hephaistion was not numbered among Alexander's closest friends ${ }^{3}$.

1 For this date see A. T. Olmstead, History of the Persian Empire, Chicago 1948 , p. 490 , and my arguments on the chronology of Philip's last year in *Philip II, Kleopatra and Karanos», RFIC 107, 1979, pp. 392-393, and *Philip and Olympias (336/7 B. C.)», in Classical Contributions: Studies in Honour of Malcolm Francis McGregor, Locust Valley, New York, 1981, pp. 55, 57.

2 J. R. Hamilton, «Alexander's Early Life», Greece and Rome 12, 1965, pp. 120 121. Equally dangerous is Hamilton's statement (p. 120) that «it is noticeable that among Alexander's close friends were few of the greater Macedonian nobility. The truth of this statement must be determined by a study not of the origins of these hetairoi but of Alexander's syntrophoi.

3 W. W. Tarn, Alexander the Great, vol. II, Cambridge 1948, p. 57. I accepted Tarn's arguments in *The Somatophylakes of Alexander the Great: Some Thoughts», Historia 27,1978 , p. 226, but with more caution in «The Conspiracy against Philotas», 
The evidence for the ages of these hetairoi is slim, and it is further complicated by the preconception that they were coeval with Alexander. But the testimony of Curtius shows that one of them, Erigyios, was considerably older than the Crown Prince, and this ought to cause us to reconsider the ages of the rest. In his description of Erigyios' monomachia with the rebel satrap Satibarzanes, Curtius (VII 4, 34) writes:

non tulit ferociam barbari dux illius exercitus Erigyios, grauis quidem aetate, sed et animi et corporis robore nulli iuuenum postferendus. Is galea dempta canitiem ostentans...

Hardly an apt description of someone between the ages of twenty-six and thirty. Not much later (Curt. VIII 2, 40), he died of unspecified, but apparently natural, causes.

There is no explicit statement about the age of Erigyios' brother, Laomedon, although it seems less likely, if Erigyios was already advanced in years, that Laomedon was a contemporary of Alexander. We do not know whether he was the older or younger brother. Arrian III 6, 6 does tell us that he was diglossos, that he knew the Persian language. Now, A. B. Bosworth points out that "Peucestas is explicitly attested to have been the only Macedonian to speak Persian" ${ }^{4}$, and he takes this to mean that Laomedon could read the language but not speak it. But it seems to me that Laomedon was placed in change of the Persian captives precisely because he could communicate with them ${ }^{5}$. Perhaps Arrian's source called Peukestas the only Macedonian to speak Persian because he considered Laomedon a Greek. It is true that Philip settled the family of Larichos in Amphipolis, but this does not mean that Laomedon was still young and raised at the Court in Pella as were the sons of some of Philip's new hetairoi. The ethnic applied to Laomedon in all but one case in Mytilenaeus ${ }^{6}$, and it is more likely that he deve-

Phoenix 31, 1977, p. 18, n. 37. Cf. now the observation of M. Renault, The Nature of Alexander, Harmondsworth 1975, repr. 1982, p. 60: «The one interesting exception was Hephaestion. There are several feasible reasons, the most obvious being that Philip, like Aristotle, thought him a good influence on Alexander...»

4 A. B. Bosworth, A Historical Commentary on Arrian's History of Alexander, vol. I, Oxford 1980, p. 283. For Peukestas see Arr. VI 30, 3; VII 6, 3; also H. Berve, Das Alexanderreich auf prosopographischer Grundlage, vol. II, Munich 1926, p. 318, no. 634.

5 I have gone so far as to suggest that the well-known story about Leonnatos' visit to the captive Persian queens involves a (deliberate?) substitution of Leonnatos for Laomedon. See W. Heckel, «Leonnatus and the Captive Persian Queens: A Case of Mistaken Identity», Studi Italiani di filologia classica 53, 1981, pp. 272-273.

6 Justin XIII 4, 12 (Mytilenaeus); Arr. Succ. 1b, 2; 1, 34; App. Syr. 52 (263); and Diod. XVIII 3, 1 all have Mıtudnvaios. Only Arr. Indike 18, 4 lists him with 
loped his bilingual talents as a young man on Lesbos rather than in Amphipolis (much less at the Court in Pella). Thus, whenever he came to the Court, he was already older than Alexander.

About Nearchos' age we can only draw inferences from the sources. $\mathrm{He}$ is known as a Cretan, once as an Amphipolitan -apparently on his own testimony (Arr. Indike 18,4)-, but he appears not to have been raised at the Court ${ }^{7}$. By contrast, the sons of Agathokles, a newly enfranchised hetairos from Krannon, were all raised at Philip's Court, and Lysimachos at least is described as Pellaios, as a Makedon, as homophylos with Demetrios Poliorketes ${ }^{8}$. And, if Nearchos himself took pains to include himself (and Laomedon) among the Makedones, other writers clearly regarded him as Greek and his influence with the marshals of the empire can be seen from Curtius' description of the succession struggle of 323 to have been negligible. He is last heard of in the year 314 as an advisor of Demetrios (Diod. XIX 69, 1), at which time he and his three colleagues are termed $\pi \rho \varepsilon \sigma \beta u ́ \tau \varepsilon \rho o{ }^{9}$. Perhaps significantly, Alexander's great admiral -at least, in his own estimation ${ }^{10}$ - played no attested part in Demetrios' naval victory at Salamis in 306 B. C., although Medios of Larissa and Marsyas of Pella did, the latter a true contemporary of Alexander the Great ${ }^{11}$. Was he too old? Or was he already dead? ${ }^{12}$.

the Macedonians. Cf. Berve, II, p. 231, who speaks of Laomedon's «Kenntnis der persischen Sprache, die er von seiner Heimat her besaß...».

7 Contra Berve, II, p. 269, no. 544, who follows Judeich in assuming that Androtimos left Lato on Crete for Amphipolis very soon after Nearchos' birth.

8 This is contrary to my own views of 1977, which appeared in print in «The Early Career of Lysimachos", Klio 64, 1982, p. 374. I now feel that Lysimachos' father was a Thessalian from Krannon, and that it was simply characteristic of Theopompos to represent Greeks who cooperated with Philip II as douloi or kolakes and as traitors to the Greek cause. See Theopompos, FGrHist 115 F81; cf. 115 F209 on Thrasydaios and Daochos. Lysimachos' early appointment to the somatophylakes may indicate an attempt by Philip to get regional representation within the group. Arybbas (Arr. III 5, 5) was apparently of Epeirot origin -perhaps even a relative of Olympias- and one of Philip's somatophylakes. For Lysimachos' acceptance as a Macedonian, see Arr. Indike 18, 3; Anab. VI 28, 4; Plut. Demetr. 44; Justin XV 3, 1; Paus. I 9, 5.

9 The others were Peithon, son of Agenor, Andronikos of Olynthos and a certain Philippos. Nothing else is known of their ages.

10 See now especially E. Badian, «Nearchus the Cretan», YCS 24, 1975, pp. 147. 170.

11 According to the Suda s. v. «Marsyas», he was a syntrophos of Alexander. For his life cf. W. Heckel, «Marsyas of Pella, Historian of Macedon», Hermes 108, 1980, pp. 446-448.

12 Polyainos 5, 35 calls Antipatrides a palaios philos of Nearchos, but their friendship need not antedate 334 B. C. On the other hand, Nearchos' Delphic proxeny, which Dittenberger (Syll. $\mathrm{I}_{3}$, p. 266) dates to 336 B. C., suggests some earlier noteworthy activity. His history too appears to have been completed before 
Ptolemaios presents an interesting methodological problem. Polybios (II 41, 1; II 71, 5) dates his death to the 124th Olympiad; to this Ps.-Lucian (Macrob. 12) adds that his death at the age of eighty-four fell two years after the accession of his son Philadelphos (i.e., in midwinter 283/2). And, by these figures, Ptolemaios' birth must be assigned to sometime in $367 / 6 \mathrm{~B}$. C. But this date is ruled out by virtually every reputable scholar because the evidence of Plutarch and Arrian suggests that Ptolemaios was coeval with Alexander! Typical is Beloch's assessment: «Wie weit diese Angabe glaubwürdig ist, mag dahingestellt bleiben; nach Plut. Alex. 10 und Arr. Anab. III 6, 5 würden wir Ptolemaeos eher für etwa gleichen Alters mit Alexander gehalten haben; dafür spricht auch die untergeordnete Stellung, die er am Anfang des asiatischen Feldzuges noch inne hatte» $\left(G G_{2}\right.$, III 2, p. 126) ${ }^{13}$. The consensus of modern scholarly opinion places his birth just before 360 , but this still makes Ptolemaios a «late bloomer», coming unto the scene as a somatophylax in 330; thirty years constituted almost a full lifetime not just for Alexander but for Leonnatos, Perdikkas, even Hephaistion, men of the King's own age, his syntrophoi. They formed the true inner circle of friends, a circle that developed at the Court already in Alexander's youth and in theirs. Youth, then, will not explain Ptolemaios' slow advancement; for younger men than he mirrored Alexander's brilliance and likewise died young. We might speculate that illegitimacy retarded his progress, or that Alexander secretly feared him as a bastard son of Philip, but rumours of Arsinoë's affair with Philip were probably Ptolemaios' own creation once he became master of Egypt and Alexander's corpse ${ }^{14}$.

Which brings us to Harpalos, the most difficult individual to assess. Berve, II, pp. $75-76$ (cf. the stemma on II, p. 440) assumed that he was the son of that Machatas whose sister, Phila, married Philip in 360 or 359 (Satyros ap. Athen. XIII 557C), and that Philippos (no. 780) and Tauron (741) were his brothers. This attractive suggestion cannot be disproved, but Harpalos' birth might yet date to $c a 365$ or earlier (i.e., in line with what tradition relates about Ptolemaios). There is a Har-

310 B. C., which is regarded as the terminus for Kleitarchos, who used Nearchos' work (C. F. Lehmann-Haupt in J. Papastavru, Amphipolis: Geschichte und Prosopographie, Klio Beiheft 37, Leipzig 1936; F. Schachermeyr in Fondation Hardt, Entretiens 22, p. 34).

13 Cf. H. Bengtson, Herrschergestalten des Hellenismus, Munich 1975, p. 11.

14 For Ptolemaios' humble origins, see Justin XIII 4, 10: ex gregario milite Alexander uirtutis causa prouexerat. But for Arsinoë and Philip, cf. Bengtson, ibid.: «Es handelt sich hier sicherlich um eine spätere Konstruktion, wie sie in der Diadochenzeit nicht für sich allein steht.» 
palos who appears to have been Philip's age, perhaps the father of Kalas, satrap of Hellespontine Phrygia. Could our Harpalos have been the same man? ${ }^{15}$. Arrian III 6, 6 tells us that Harpalos was unfit for military service, and we tend to assume an inherited or boyhood deformity. But this again is to put the cart before the horse. If Harpalos was one of Alexander's syntrophoi, he is certainly never connected with that group in any way. In fact, the members of this group, it may be suggested, had one common characteristic: all laboured at a disadvantage within the Macedonian system. Erigyios, Laomedon and Nearchos were Greeks; Harpalos was physically, and Ptolemaios perhaps socially, handicapped. None ever attained the stature or enjoyed the meteoric success of Alexander's real boyhood friends, though Ptolemaios (the Macedonian) came close.

I conclude that these hetairoi were older than Alexander and appointed by Philip as his advisors, just as later Antigonos appointed advisors (including our Nearchos) for his son Demetrios (Diod. XIX 69, 1). It was, after all, one of the functions of the King's hetairoi to advise (symbouleuein), and it is because they gave bad advice, advice that was against Philip's interests, that they were banished. This sort-lived and dangerous office may have saved them from obscurity, for Alexander rewarded their loyalty with a significant, if not dazzling, display of gratitude. But it was the memoirs of two of their number that translated this gratitude into lifelong devotion. Like Arrian, who used them both, we trust the authority of their works because of their connexion with Alexander, and we accept this connexion on their authority ${ }^{16}$.

WALDemar Heckel

15 This Harpalos is generally thought to be a brother of Derdas and Machatas, and an uncle of the treasurer (0. Hoffmann, Die Makedonen: ihre Sprache und ihr Volkstum, Göttingen 1906, p. 165, following J. G. Droysen, Hellenismus $\mathbf{I}_{2}$, pp. 87, 183; cf. Berve, II, p. 440).

16 See the praefatio to Arrian's Anabasis. On Nearchos, Badian's introduction to the problem is to the point: "The reputation of Nearchus, the Cretan from Amphipolis, shines like a good deed in the admittedly naughty world of Alexander historians» (YCS 24, 1975, p. 145). 